\title{
GLACIAL CRUSHING OF LIMESTONE AND THE PRODUCTION OF CARBONATE-RICH SILTS IN A PLEISTOCENE GLACIOFLUVIAL SYSTEM: A POTENTIAL SOURCE OF LOESS IN SOUTHERN EUROPE
}

\author{
KATHRYN R. ADAMSON ${ }^{1,2}$, JAMIE C. WOODWARD ${ }^{3}$ and PHILIP D. HUGHES ${ }^{3}$ \\ ${ }^{1}$ Geography, Queen Mary, University of London, London, UK \\ ${ }^{2}$ Geography, School of Science and the Environment, Manchester Metropolitan University, \\ Manchester, UK \\ ${ }^{3}$ Geography, School of Environment, Education, and Development, The University of Manchester, \\ Manchester, UK
}

\begin{abstract}
Adamson, K.R., Woodward, J.C. and Hughes, P.D., 2014. Glacial crushing of limestone and the production of carbonate-rich silts in a Pleistocene glaciofluvial system: a potential source of loess in Southern Europe. Geografiska

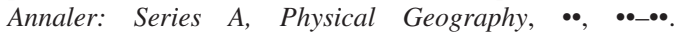
DOI: $10.1111 /$ geoa. 12054
\end{abstract}

\begin{abstract}
This paper explores the modification of limestone bedrock and fine-grained sediment within the Pleistocene glacial and proglacial environments of the Orjen massif in western Montenegro. We have characterised the finegrained components of till and outwash using lithological and particle size data. Two main types of fine-grained outwash sediment have been recognised and each is associated with a distinctive meltwater route. Fine-grained sediments deposited downstream of bedrock gorges (type 1 meltwater route) typically display a bimodal particle size distribution, where the carbonate silt fraction $(10-60 \mu \mathrm{m})$ has been depleted and non-carbonate silts become dominant. This probably reflects both physical sorting and corrosion of the fine-grained limestone sediment within the proglacial fluvial environment. The $10-60 \mu \mathrm{m}$ component matches the particle size characteristics of typical loess. Fine-grained outwash deposits from directly in front of the former ice margin (type 2 meltwater route) show unimodal particle size distributions which more closely resemble the grain size characteristics of the glacial till, but they also show evidence of silt depletion. We argue that the fine-grained sediment exported from glaciated limestone catchments during the cold stages of the Pleistocene formed an important source of the carbonate-rich loess in this region.
\end{abstract}

Key words: Pleistocene, karst, Mediterranean, glaciation, bedrock crushing, proglacial zone, grain size changes, loess

\section{Introduction}

As ice sheets advanced during cold stages of the Pleistocene, large quantities of silt $(2-63 \mu \mathrm{m})$ were produced by glacial crushing of bedrock (Smalley 1990, 1995). Silts were deflated from the wide braidplains of proglacial rivers and often transported long distances to be deposited as loess (Pye 1987). In the Mediterranean, ice caps and valley glaciers developed on the highest uplands - many of which are dominated by limestone bedrock (Hughes and Woodward 2009). The meltwater streams draining these ice masses transported large volumes of limestone-derived, fine-grained sediment (Woodward et al. 1992; Adamson et al. 2014). This carbonate-rich silt was an important component of the cold stage suspended load in many Mediterranean rivers and it has been recognised in a wide range of depositional settings downstream of the glaciated uplands. These include the finegrained matrix in coarse fluvial gravels (Lewin et al. 1991), slackwater sediment records (Woodward et al. 2008), lacustrine sequences (Giraudi et al. 2011), and rockshelter sediment records (Woodward and Bailey 2000). Many of the loess deposits of Southern Europe contain a significant component of calcium carbonate (Marković et al. 2009). There is a need for an improved understanding of the fine sediment pathways and processes from bedrock sources to glacial and fluvial settings in such limestone catchments.

This paper examines the lithology and grain size characteristics of fine-grained deposits from a series of upland limestone catchments draining the Orjen massif in western Montenegro (Fig. 1). We examine the nature of the glaciated limestone bedrock, the limestone-derived till, and the 

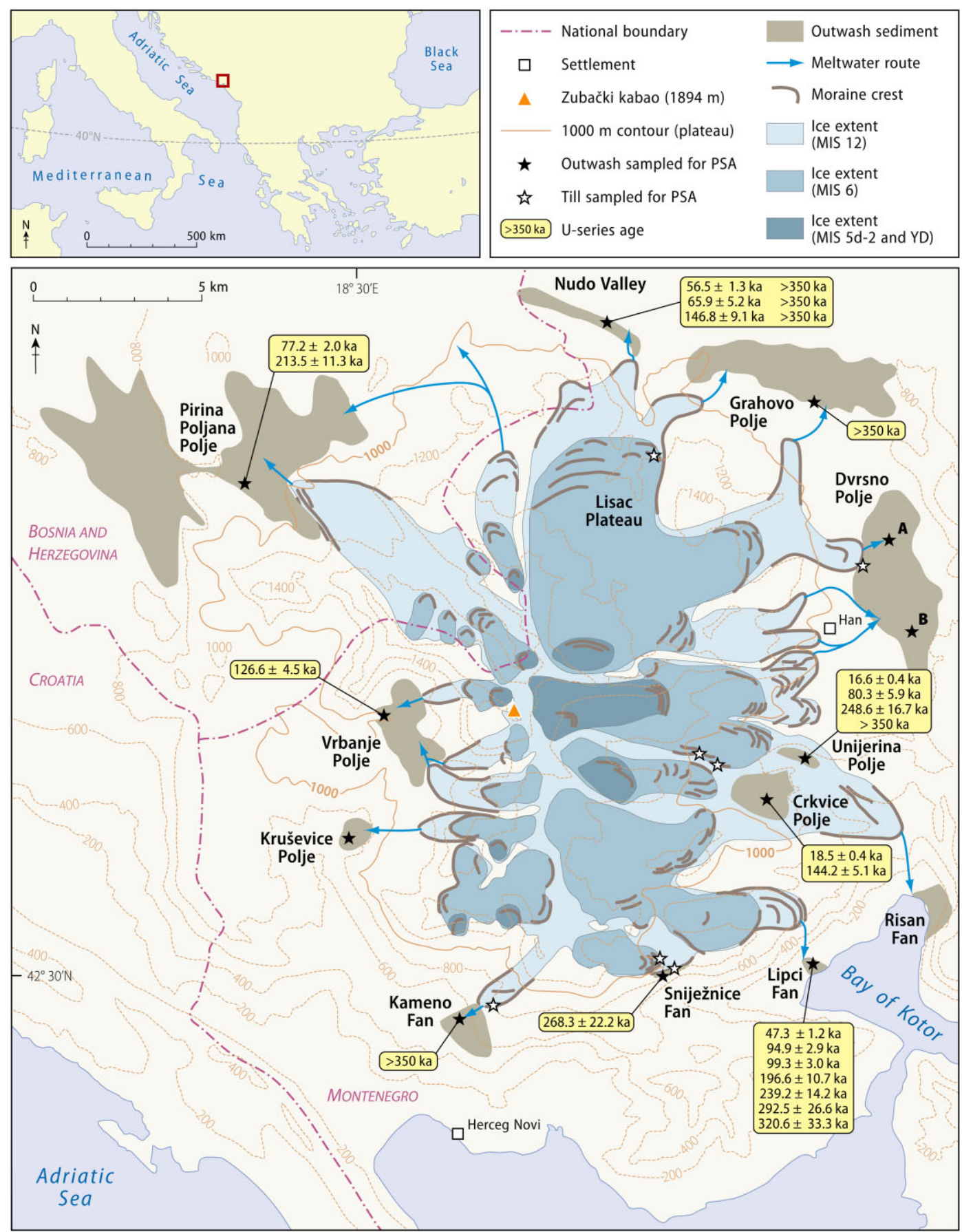

Fig. 1. The study region of the Orjen massif, western Montenegro. The Pleistocene ice margins of Hughes et al. (2010), U-series ages, and sample locations are indicated. Dvrsno transects A and B are also marked. 
proglacial fluvial deposits downstream to better understand the comminution and sorting processes in glaciated karst basins. A key aim is to establish whether the glaciated limestone catchments of Southern Europe could have been important sources of carbonate-rich aeolian dust during cold stages of the Pleistocene.

\section{Geomorphological setting}

Orjen (highest peak Zubački kabao, 1894 m a.s.l.; Fig. 1) is a large, steep-sided and intensively karstified limestone massif on the border of western Montenegro, Croatia, and Bosnia-Herzegovina (Fig. 1). The landscape is characterised by extensive limestone pavements, dolines, and poljes of various sizes (Fig. 2), in addition to an extensive subterranean drainage network (Magaš 2002). An extensive plateau surface at $c .1000 \mathrm{~m}$ a.s.l. is flanked by valleys and deeply incised gorges which formed important surface meltwater routes during the Pleistocene (see Lewin and Woodward, 2009). Orjen is surrounded by a range of alluvial depositional settings, including fans and poljes (Fig. 2d). Three main phases of Pleistocene glacial activity have been identified. These have been U-series dated $(n=12)$ and correlated to Marine Isotope Stages (MIS): 12, 6, 5d-2 (Hughes et al. 2010). There is also evidence for glacial activity during the Younger Dryas. During the most extensive glacial phase (that took place during MIS 12), ice extended beyond the massif and thick sequences of outwash were deposited in the surrounding basins (Kotorska-Sušica Member, Table 1). During MIS 6, 5d-2, and the Younger Dryas, ice was restricted to the plateau and highest cirques (Fig. 1). There is only very limited evidence of Pleistocene fluvial sedimentation after MIS 12), (Adamson et al. 2014). We have argued that this reflects both a decrease in glacial sediment supply to the fluvial system and an increasing dominance of subterranean karst flow at the expense of surface runoff as the upland headwaters and lowland basins uncoupled (Adamson et al. 2014). The glacial and alluvial sediments of MIS 12 are therefore the focus of this paper (Fig. 2).

Two types of surface meltwater route have been identified around the Orjen massif (Fig. 2). These conveyed large volumes of meltwater and sediment into the surrounding depocentres during the Middle Pleistocene. In the case of type 1 meltwater routes, the ice margins were situated on the plateau and outwash was conveyed downstream via bedrock gorges. These cases include: Grahovo, Dvrsno (south) and Kruševice poljes; Lipci fan; and Nudo valley (Fig. 1). In the case of type 2 meltwater routes, ice extended to much lower elevations beyond the $1000 \mathrm{~m}$ contour so that the ice margin lay within the main zone of outwash accumulation. Outwash was delivered directly from the ice margin at the following sites: Dvrsno (north), Vrbanje, Unijerina and Crkvice poljes; and Kameno fan (Fig. 1).

\section{Methods \\ Field sampling}

Samples of limestone bedrock $(n=16)$, till matrix $(n=7)$, and the fine-grained matrix from gravelly outwash deposits $(n=147)$ were collected from 47 exposures across the Orjen massif. We sampled seven moraines from different outlet lobes of the Orjen ice cap and the 12 areas of outwash deposition (poljes, river terraces, and alluvial fans) surrounding the plateau shown on Fig. 1. This sampling framework was designed to ensure systematic coverage of the glacial and alluvial records and their limestone bedrock sources.

\section{Insoluble residue and particle size analysis}

The insoluble residue content of the source limestone bedrock was determined by analysing a sample of limestone clasts selected from bulk samples of alluvial sediment from 16 sites. This had the advantage of providing material that was representative of the up-valley bedrock sources. The carbonate component of the bedrock was determined by dissolving several gravel-sized clasts in $10 \%(\mathrm{v} / \mathrm{v})$ hydrochloric acid $(\mathrm{HCl})$. The particle size characteristics of the bedrock insoluble residues were then determined (Woodward and Bailey 2000) as described below. All the particle size analyses in this study were carried out using a Malvern Mastersizer 2000 laser diffraction particle size analyser (McCave et al. 2006; Goossens 2008). Laser diffraction is widely regarded as providing the best reproducibility (Syvitski et al. 1991; Konert and Vandenberghe 1997; Sperazza et al. 2004; McCave et al. 2006; Goossens 2008).

All the Pleistocene glacial and fluvial samples were initially screened through a $2 \mathrm{~mm}$ mesh. The particle size characteristics of these samples were then analysed in two separate bulk size fractions $(<2 \mathrm{~mm}$ and $<63 \mu \mathrm{m})$ using the Malvern Master- 

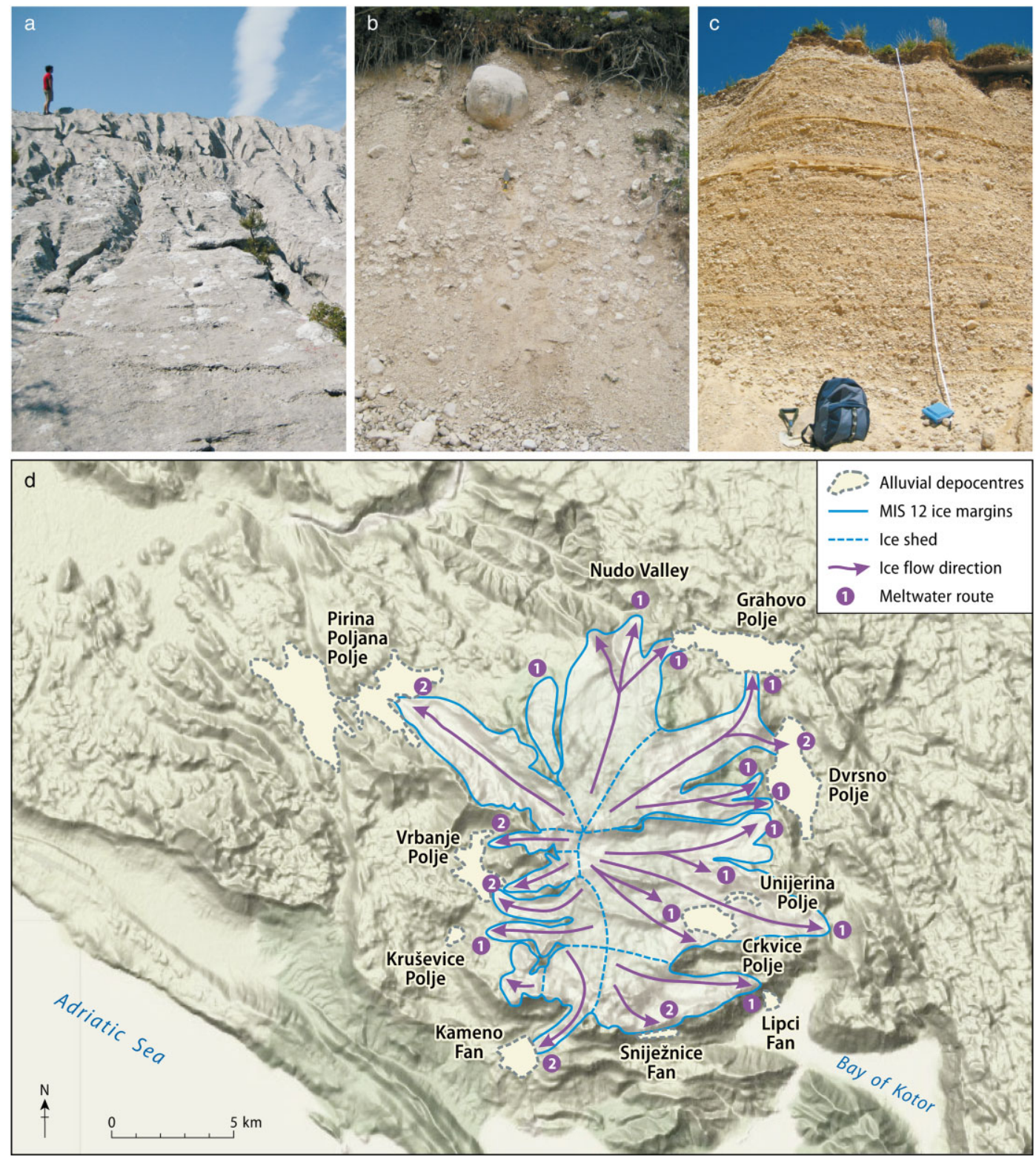

Fig. 2. The limestone terrain of the Orjen massif: (a) Limestone bedrock typical of the Orjen region; (b) glacial till exposure on the Lisac Plateau (>1000 m a.s.l.), north Orjen. Note the trowel for scale; (c) outwash sediments in the northern section of Dvrsno polje, east Orjen; (d) DEM of the Orjen massif and surrounding depocentres analysed in this study. Meltwater routes (type 1 and 2) are indicated. DEM from GoogleEarth.

sizer. The $<63 \mu \mathrm{m}$ component was calculated as a percentage of the total sample weight $(<2 \mathrm{~mm})$. Splitting the samples in this way ensured that the finest component $(<63 \mu \mathrm{m})$, which is the prime focus of this study, was not obscured by larger sand-sized particles during laser particle size analysis (Goossens 2008). The sieved bulk samples were then divided into two further sub-samples. One of these was analysed as a bulk sample (all lithologies including carbonates) for particle size analysis. These data are given the notation $\mathrm{C}$ (carbonate) in the results. The second was used to 
Table 1. The alluvial chronostratigraphy of the Orjen massif (see Adamson et al. 2014) with the glacial stratigraphy developed by Hughes et al. (2010).

\begin{tabular}{|c|c|c|c|c|}
\hline Member & Exposures & $\begin{array}{l}\text { U-series age } \\
\text { (ka) }\end{array}$ & MIS & $\begin{array}{c}\text { Glacial record } \\
\text { (Hughes } \text { et al. } 2010)\end{array}$ \\
\hline Krivošije Member & $\begin{array}{l}\text { Vrbanje } \\
\text { Crkvice }\end{array}$ & $\begin{array}{r}126.5 \pm 4.5 \\
144 \pm 5.1 \\
18.5 \pm 0.4\end{array}$ & 6 & Crkvice Member \\
\hline Kotorska-Sušica Member ${ }^{a}$ & $\begin{array}{l}\text { Dvrsno } \\
\text { Grahovo } \\
\text { Kruševice } \\
\text { Vrbanje } \\
\text { Pirina Poljana } \\
\text { Nudo Arandelovo (highest terrace) } \\
\text { Nudo Vućiya } \\
\text { Nudo Kamiseyo } \\
\text { Nudo Javora } \\
\text { Nudo Zaslap (lowest terrace) } \\
\text { Kameno } \\
\text { Lipci } \\
\text { Unijerina }\end{array}$ & $\begin{array}{c}- \\
>350 \\
- \\
- \\
213 \pm 11.3 \\
77.2 \pm 2.0 \\
65.9 \pm 5.2 \\
56.5 \pm 1.3 \\
>350 \\
- \\
>350 \\
>350 \\
146.8 \pm 9.1 \\
>350 \\
320.6 \pm 33.4 \\
292.5 \pm 26.7 \\
239.2 \pm 14.2 \\
196.6 \pm 10.8 \\
99.3 \pm 3.1 \\
94.9 \pm 2.10 \\
47.3 \pm 1.3 \\
>350 \\
248.6 \pm 16.7 \\
80.3 \pm 5.9 \\
16.6 \pm 0.4 \\
268.3 \pm 22.2\end{array}$ & $12-8$ & Knezlaz Member \\
\hline
\end{tabular}

${ }^{\text {a }}$ It is likely that the Kotorska-Sušica member is dominated by MIS 12 sediments (see discussion in Adamson et al. 2014).

establish the non-carbonate component of the matrix using a $10 \%(\mathrm{v} / \mathrm{v}) \mathrm{HCl}$ digestion. These data are given the notation $\mathrm{NC}$ (non-carbonate) in the results. Following acid digestion, the insoluble residues were dried and reweighed to determine the calcium carbonate $\left(\mathrm{CaCO}_{3}\right)$ content $(\%$ of the bulk sediment matrix by weight). All the insoluble residues (from bedrock, till, and alluvial samples) were then wet sieved through a $63 \mu \mathrm{m}$ mesh. Each fraction $(<2 \mathrm{~mm}$ to $>63 \mu \mathrm{m}$ and $<63 \mu \mathrm{m})$ was dried and weighed. These fractions typically weighed $<1 \mathrm{~g}$ and were analysed in the Malvern Mastersizer using the $2000 \mu \mathrm{p}$ nano sample dispersion unit. The larger bulk samples (with the carbonate fraction) were analysed using a $2000 \mathrm{G}$ dispersion unit. All samples were dispersed in deionised water and $5 \mathrm{ml}$ dilute $(5 \% \mathrm{v} / \mathrm{v})$ sodium hexametaphosphate and were analysed three times with bracketing cleaning cycles. Ten randomly selected samples were used to calibrate the results between the 2000 $\mathrm{G}$ and $2000 \mu \mathrm{p}$ units. The results were directly comparable.

\section{Results}

Bedrock insoluble residue particle size distribution

Insoluble residues typically account for less than $1.5 \%$ of bedrock samples (Table 2; mean value $1.2 \%$, range $1.6 \%$, excluding two outliers). The samples from Pirina Poljana (3.6\%) and the Vućiya Unit of the Nudo valley (3.3\%) yielded the highest insoluble residue components. The particle size distribution (PSD) $(<2 \mathrm{~mm})$ of the insoluble residue of all limestone clasts is unimodal and dominated by clays and fine silts $(2-11 \mu \mathrm{m})$ (Fig. 3a). Some samples (e.g. Dvrsno and Unijerina) also contain a minor coarse silt component.

\section{Glacial fine sediment particle size distribution}

The seven bulk $(<2 \mathrm{~mm})$ till samples display a bimodal PSD with dominant peaks at $1-10 \mu \mathrm{m}$ and $1000 \mu \mathrm{m}$ (Fig. 3c). The fine-grained component of the tills $(<63 \mu \mathrm{m})$ is dominated by glacially comminuted limestone particles. The $<63 \mu$ m components 
Table 2. Insoluble residue (non-carbonate) component of bedrock samples from outwash gravels surrounding Orjen. These samples are deemed to be representative of the bedrock outcrops upstream of each location.

\begin{tabular}{lc}
\hline Sample location & $\begin{array}{c}\text { \% Insoluble } \\
\text { residue }\end{array}$ \\
\hline Dvrsno polje & 0.9 \\
Grahovo polje & 1.5 \\
Kruševice polje & 1.0 \\
Vrbanje polje & 1.9 \\
Pirina Poljana polje & 3.6 \\
Crkvice polje & 1.1 \\
Unijerina polje & 1.2 \\
Kameno alluvial fan & 0.4 \\
Lipci alluvial fan & 1.5 \\
Sniježnice fan & 1.3 \\
Nudo valley Zaslap Unit (lowest terrace) & 1.5 \\
Nudo valley Javora Unit & 0.8 \\
Nudo valley Kamiseyo Unit & 2.0 \\
Nudo valley Vućiya Unit & 3.3 \\
Nudo valley Arandelovo Unit & 0.5 \\
$\quad$ highest terrace) & 1.2 \\
Nudo - Zaslap Tributary & \\
\hline
\end{tabular}

display much flatter distributions with modal peaks $<10 \mu \mathrm{m}$ (Fig. 3b). The insoluble residue of the glacially comminuted fines $(<63 \mu \mathrm{m})$ displays a coarser PSD than the bulk (with carbonate) fines. The insoluble residues account for $2.1-15.5 \%$ of the $<63 \mu \mathrm{m}$ fraction (Table 3). This insoluble residue enrichment from bedrock to till is highest at Sniježnice on the southern flank of Orjen $(9.9 \%$ and $15.5 \%)$.

\section{Alluvial sediment particle size distribution}

The stratigraphy and sedimentology of the deposits in the 12 main sectors of outwash deposition surrounding Mount Orjen (Fig. 1) are reported in detail in Adamson et al. (2014). Our analyses of the fine-grained alluvial sediments at three of these sites, which are deemed to be representative of the wider Orjen record, are discussed in detail here. These results are summarised in Table 4.

\section{Dvrsno polje}

Dvrsno polje $\left(7.5 \mathrm{~km}^{2}\right)$ lies beyond the limestone plateau and outside the MIS 12 ice margins (Fig. 1). It was fed by two major meltwater pathways. Aggregate quarries in this polje provide extensive exposures (up to $10 \mathrm{~m}$ in height) in the outwash deposits. Multiple sections were logged along two transects downstream of each meltwater entry zone. A prominent moraine ridge shows that ice extended into the northern sector of the polje during MIS 12 (Hughes et al. 2010) (Fig. 1).

Transect A (sections D1-D7) lies downstream of this large MIS 12 moraine (type 2 meltwater route). At distances $<1 \mathrm{~km}$ from the ice margin, the $<63 \mu \mathrm{m}$ PSD is dominated by fine silts and clays (Fig. 4) showing a broad unimodal distribution similar to that of the glacial fines. At distances beyond c. $1 \mathrm{~km}$ from the ice margin (Fig. 4), coarser silt becomes more prominent but the $<63 \mu \mathrm{m}$ fraction is still dominated by the finest clays $(1-4 \mu \mathrm{m})$ (Fig. 4). The insoluble residue of the $<63 \mu \mathrm{m}$ fraction accounts for up to $5.8 \%$ of the matrix at site D7 (Table 4) and $20 \%$ of the finest clay horizons. These values are particularly high for a region dominated by limestone bedrock ( $0.9 \%$ insoluble residue within clasts; Table 2) (see Woodward and Bailey 2000).

In the southern part of Dvrsno polje, the ice margin was confined to the higher elevation plateau $(>1000 \mathrm{~m}$ a.s.1.) and meltwater drained into the polje via the bedrock gap at Han (type 1 meltwater route). Transect B (sections D8 and D9) lies $c$. $2.9 \mathrm{~km}$ from the ice margin. The fine matrix component $(<63 \mu \mathrm{m})$ of transect B displays a strongly bimodal PSD which is much more pronounced than that of transect A (Fig. 4). At D8 the insoluble residue contributes up to $2.8 \%$ of the sediment matrix and $17 \%$ of the finest clay horizons (Table 4). This is consistent with the insoluble residue concentrations observed on transect $\mathrm{A}$. The $<63 \mu \mathrm{m}$ fraction demonstrates a clear transition from unimodal to bimodal PSDs at distances $>1 \mathrm{~km}$ from the former ice margin on Transect $\mathrm{B}$. The peak of the $<63 \mu \mathrm{m}$ insoluble residue PSD curve coincides with the minimum point of the bimodal bulk sediment curve. This is particularly evident at section D8 (Fig. 4).

\section{Kameno fan}

The Kameno fan has developed downstream of a large MIS 12 moraine (type 2 meltwater pathway) at the southern edge of the Orjen plateau (Fig. 1). Between 0.15 and $1 \mathrm{~km}$ from the former ice margin, the exposures display massive sands and gravels which become increasingly stratified down-fan. Bulk matrix samples from section $\mathrm{K} 1$, closest to the moraine, show a unimodal PSD within both the $<2 \mathrm{~mm}$ (dominantly coarse sand) and $<63 \mu \mathrm{m}$ (dominantly silt) fractions (Fig. 5). Moving down fan, the $<63 \mu \mathrm{m}$ component becomes increasingly dominated by clays and very fine silts $(1-4 \mu \mathrm{m})$ at $\mathrm{K} 2$. The coarse silt component is more prominent at K8 (Fig. 5). 

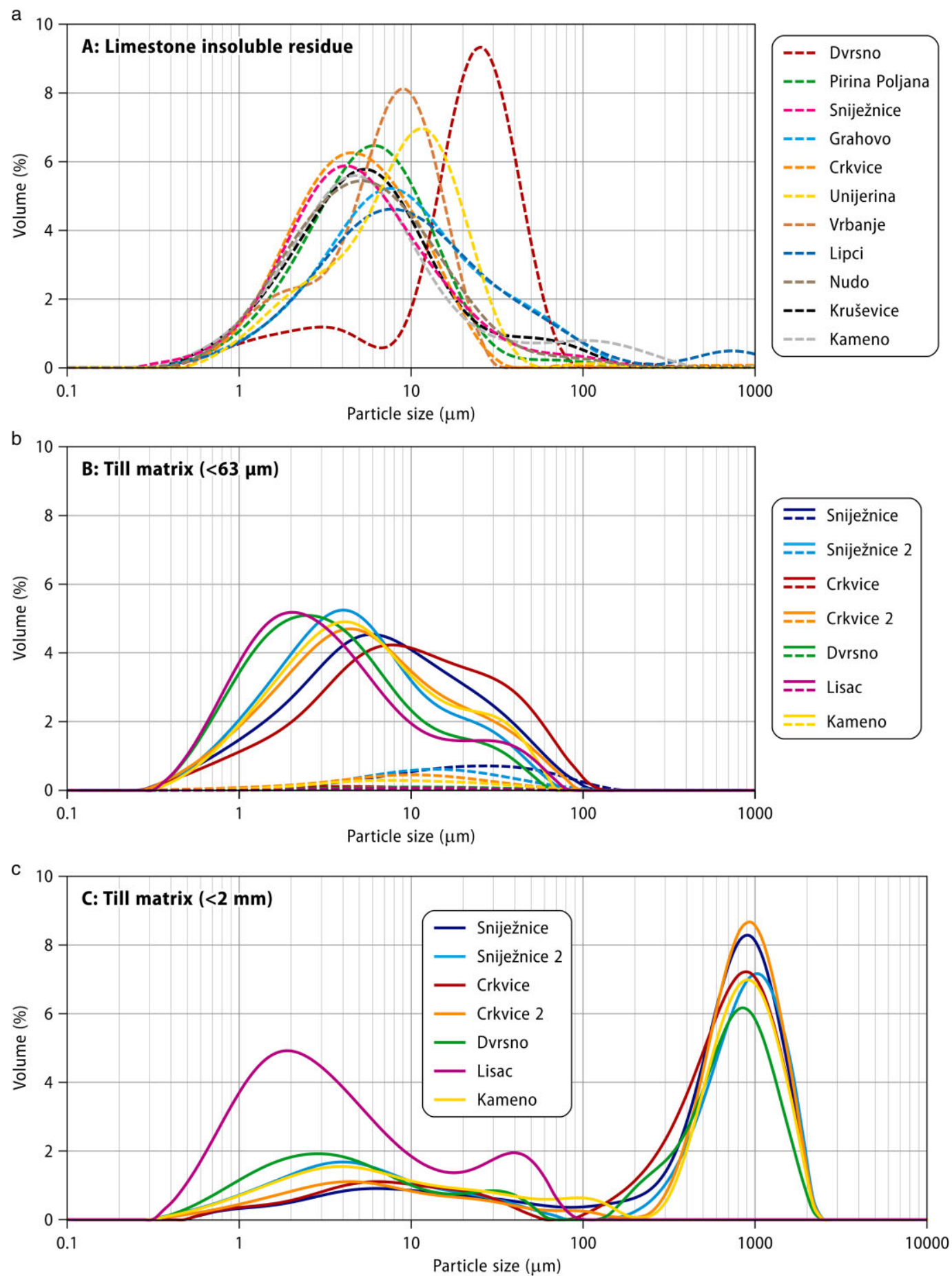

Fig. 3. (a) Particle size distribution of the insoluble residue (non-carbonate) component of bedrock clast samples. The particle size distribution of till matrix samples from moraines surrounding the Orjen massif at (b) $<63 \mu \mathrm{m}$ and (c) $<2 \mathrm{~mm}$. Solid lines represent non-acidified sediment samples. Dashed lines represent the insoluble residue component throughout this paper. 
Table 3. Carbonate content data from the sediment matrix of glacial till across the Orjen massif displayed as $\%$ insoluble residue (non-carbonate, $\mathrm{NC}$ ) and carbonate $(\mathrm{C})$ of the bulk sediment by size fraction: $<2 \mathrm{~mm}$ to $>63 \mu \mathrm{m}$ and $<63 \mu \mathrm{m}$. Marine isotope stages (MIS) follow the correlations of Hughes et al. (2010). Sample locations are shown on Figure 1.

\begin{tabular}{lccccc}
\hline Moraine (MIS) & \multicolumn{2}{c}{ Sand fraction } & & \multicolumn{2}{c}{ Silt and clay fraction } \\
\cline { 2 - 3 } \cline { 5 - 6 } & $<2 \mathrm{~mm}$ to $>63 \mu \mathrm{m}(\mathrm{NC} \%)$ & $<2 \mathrm{~mm}$ to $>63 \mu \mathrm{m}(\mathrm{C} \%)$ & & $<63 \mu \mathrm{m}(\mathrm{NC} \%)$ & $<63 \mu \mathrm{m}(\mathrm{C} \%)$ \\
\hline Lisac (MIS 6) & 0.1 & 68.6 & 5.0 & 26.3 \\
Dvrsno (MIS 12) & 0.2 & 54.7 & 4.8 & 4.1 \\
Crkvice 1 (MIS 6) & 0.2 & 81.9 & 7.3 & 15.8 \\
Crkvice 2 (MIS 6) & 0.3 & 74.6 & 57.1 & 17.8 \\
Sniježnice 1 (MIS 12) & 0.3 & 66.3 & 9.9 & 27.1 \\
Sniježnice 2 (MIS 6) & 0.1 & 72.0 & 2.1 & 23.7 \\
Kameno (MIS 12) & 0.1 & & & 25.7 \\
\hline
\end{tabular}

Table 4. Carbonate and non-carbonate content of outwash matrix samples at Dvrsno polje, Kameno alluvial fan and Unijerina valley displayed as \% insoluble residue (non-carbonate, NC) and carbonate (C) of the bulk sediment by size fraction: $<2 \mathrm{~mm}$ to $>63 \mu \mathrm{m}$ (sand fraction) and $<63 \mu \mathrm{m}$ (silt and clay fraction). MWR indicates meltwater route.

\begin{tabular}{|c|c|c|c|c|}
\hline \multirow[t]{2}{*}{ Sampled exposure } & \multicolumn{2}{|c|}{ Sand fraction } & \multicolumn{2}{|c|}{ Silt and clay fraction } \\
\hline & $<2 \mathrm{~mm}$ to $>63 \mu \mathrm{m}(\mathrm{NC} \%)$ & $<2 \mathrm{~mm}$ to $>63 \mu \mathrm{m}(\mathrm{C} \%)$ & $<63 \mu \mathrm{m}(\mathrm{NC} \%)$ & $<63 \mu \mathrm{m}(\mathrm{C} \%)$ \\
\hline \multicolumn{5}{|c|}{ Dvrsno polje - transect A (type 2 MWR) } \\
\hline Section D1 & 0.10 & 87.60 & 2.90 & 9.50 \\
\hline Section D2 & 0.00 & 89.00 & 4.30 & 6.70 \\
\hline Section D3 & 0.10 & 90.30 & 3.30 & 6.40 \\
\hline Section D4 & 0.90 & 89.10 & 4.70 & 5.30 \\
\hline Section D5 & 0.10 & 84.50 & 5.20 & 10.10 \\
\hline Section D6 & 0.20 & 85.70 & 3.20 & 10.90 \\
\hline Section D7 & 0.10 & 94.00 & 5.80 & 0.10 \\
\hline \multicolumn{5}{|c|}{ Dvrsno polje - transect $B$ (type 1 MWR) } \\
\hline Section D8 & 0.00 & 78.40 & 2.80 & 18.80 \\
\hline Section D9 & 0.10 & 96.80 & 1.40 & 1.80 \\
\hline \multicolumn{5}{|c|}{ Kameno Fan (type $2 \mathrm{MWR}$ ) } \\
\hline Section K1 & 0.10 & 78.90 & 6.10 & 14.90 \\
\hline Section K2 & 0.00 & 84.10 & 2.90 & 12.90 \\
\hline Section K4 & 1.00 & 77.00 & 1.20 & 20.90 \\
\hline Section K7 & 0.10 & 88.20 & 1.80 & 9.90 \\
\hline Section K8 & 0.10 & 82.50 & 5.20 & 12.20 \\
\hline \multicolumn{5}{|c|}{ Unijerina polje (type $1 \mathrm{MWR}$ ) } \\
\hline Section U1 & 0.20 & 92.40 & 2.00 & 5.50 \\
\hline Section U2 & 0.80 & 81.50 & 4.00 & 13.70 \\
\hline Section U3a & 7.00 & 71.10 & 3.30 & 18.50 \\
\hline Section U3b & 20.60 & 37.30 & 5.60 & 36.50 \\
\hline
\end{tabular}

The insoluble residue accounts for up to $6.2 \%$ of the sediment matrix (Table 4) and is concentrated into the $<63 \mu \mathrm{m}$ size fraction (Fig. 5). Clayrich layers contain elevated concentrations of insoluble residue $(22.1 \%)$ even though the bedrock values at this site are only $0.4 \%$ (Tables 2 and 4 ). In the central portion of the fan (section K4), noncarbonate lithologies are concentrated in the sand fraction where they represent up to $1 \%$ of the $<2 \mathrm{~mm}$ matrix compared with the negligible $(0.1 \%)$ concentrations observed elsewhere across the fan. This pattern is also evident within the matrix samples at Dvrsno polje, northeast Orjen, which show a small increase in sand-sized insoluble residue within the central portion of the polje.

\section{Unijerina polje}

Unijerina polje, east Orjen, lies on the upland plateau, inside the MIS 12 ice margins and $c$. $1.9 \mathrm{~km}$ downstream of the MIS 6 moraines at Crkvice (Hughes et al. 2010; Fig. 1). During Pleis- 
a
Transect $A$

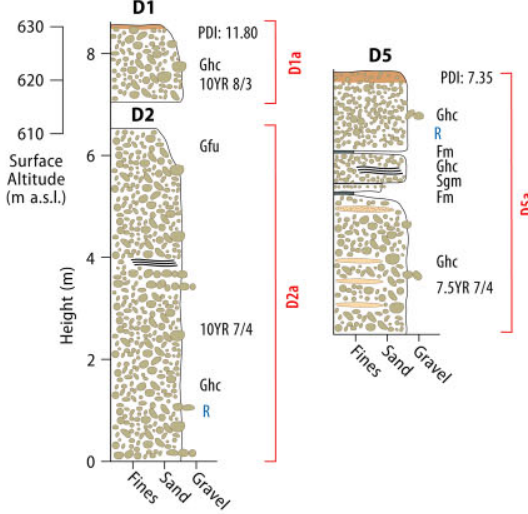

Transect B

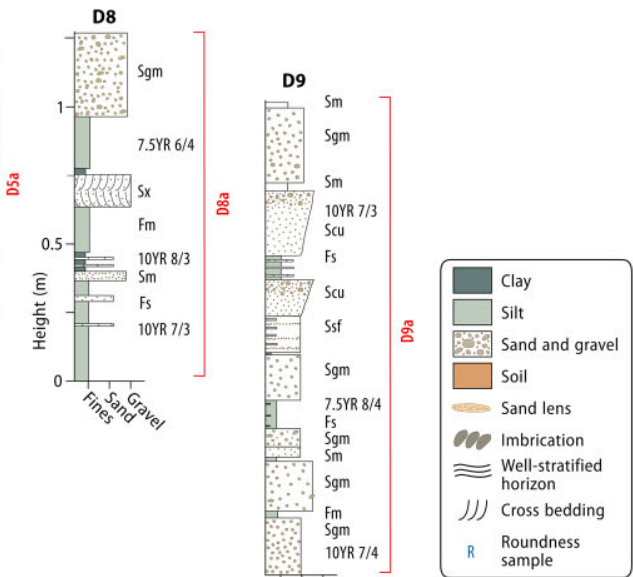

\begin{tabular}{|c|c|c|c|c|c|}
\hline \multicolumn{4}{|c|}{ Facies codes and descriptions } & \multirow{2}{*}{$\begin{array}{l}\text { GRm } \\
\text { Scu }\end{array}$} & \multirow{2}{*}{$\begin{array}{l}\text { Granules, matrix supported } \\
\text { Sand coarsening upwards }\end{array}$} \\
\hline Dmm & Diamicton, matrix supported, massive & Ghi & Gravels, horizontally bedded, imbrication & & \\
\hline $\mathrm{Fm}$ & Fine sand/silty layer, massive & Ghm & Gravels, horizontally bedded, matrix supported & Sfu & Sand fining upwards \\
\hline Fs & Fines, interstratified & Gmc & Gravels, massive, dast supported & Sgm & Sand, granular, massive \\
\hline Gcu & Gravels, coarsening upwards & Gmi & Gravels, massive, imbrication & Sh & Sand, horizontally bedded \\
\hline Gfu & Gravels, fining upwards & GRC & Granules, clast supported & Sm & Sand, massive \\
\hline Ghe & Gravels, horizontally bedded, clast supported & GRh & Granules, horizontally bedded/plane bedded & Ssf & Sand, interstratified fine layers \\
\hline Ghf & Gravels, horizontally bedded, fine layers & GRCu & Granules, coarsening upwards & $5 x$ & Sand, cross stratified \\
\hline
\end{tabular}

b
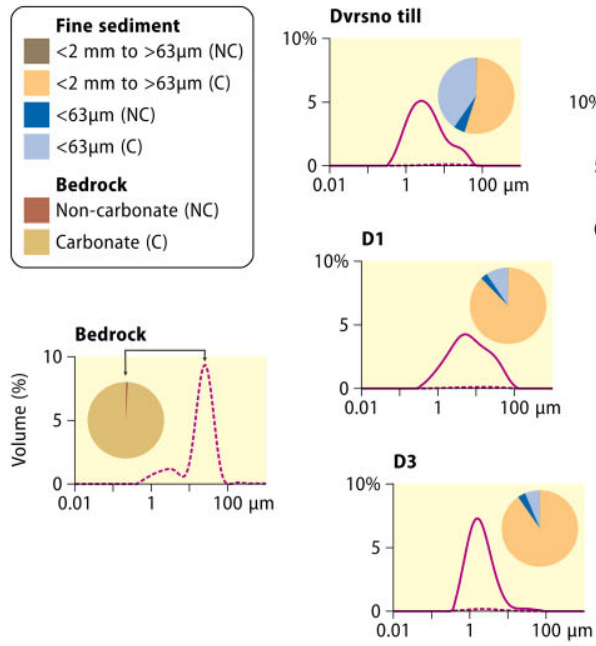

Long profile of sampled outwash transect A

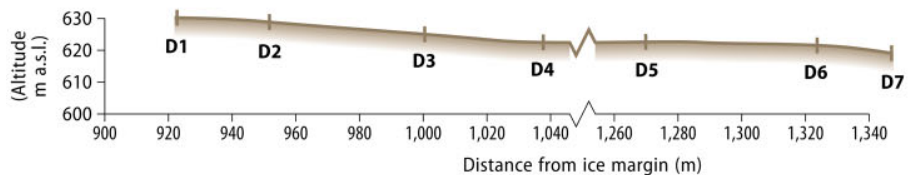

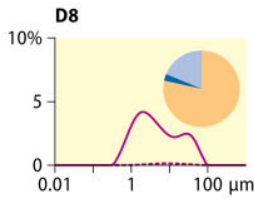

D7
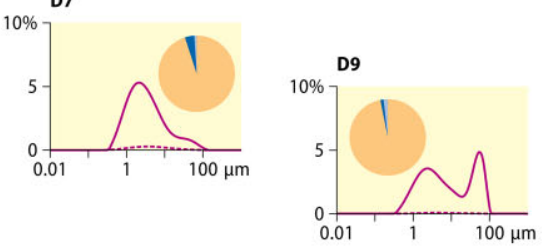

Outwash transect B

D8

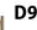

Fig. 4. (a) Key sedimentary logs for Pleistocene fluvial sediments from Dvrsno polje. (b) Pie charts for till and outwash show bulk $(<2 \mathrm{~mm})$ lithology. Particle size curves for till and outwash are for the fraction $<63 \mu \mathrm{m}$. Solid lines $=$ non-acidified samples, dashed lines $=$ insoluble residue component. 
a

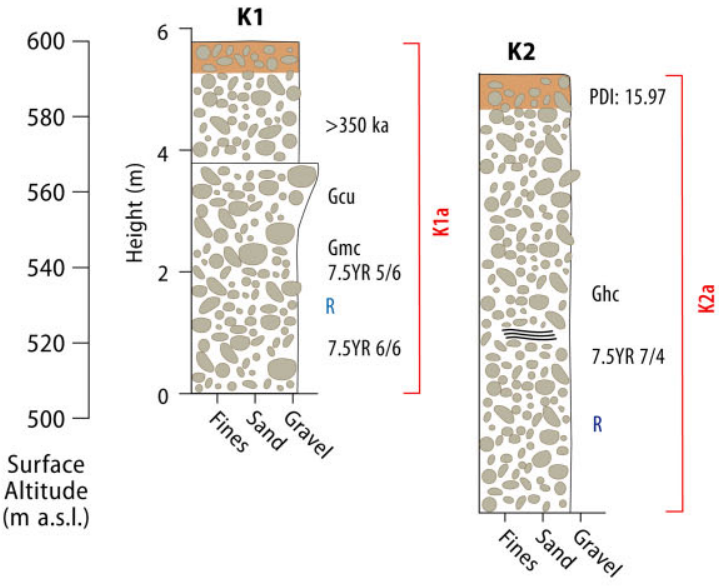

\begin{tabular}{|c|c|c|c|}
\hline Clay & Sand and gravel & $\approx$ & Well-stratified horizon \\
\hline Silt & Sand lens & נر & Cross bedding \\
\hline Soil & 000 Imbrication & $\mathrm{R}$ & Roundness sample \\
\hline
\end{tabular}

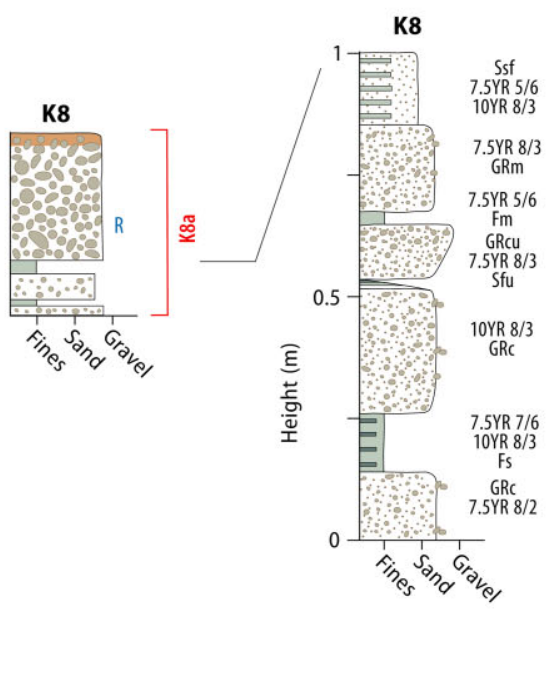

b
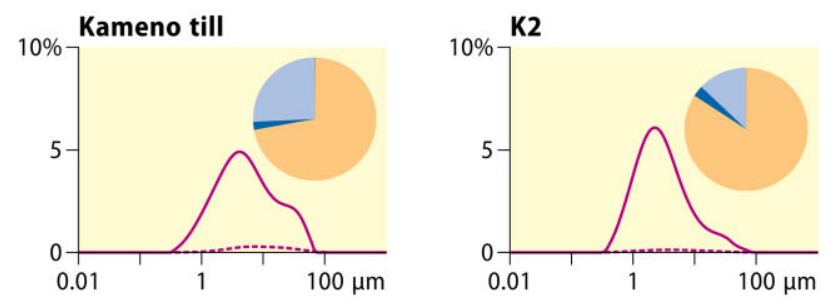

Fine sediment

$<2 \mathrm{~mm}$ to $>63 \mu \mathrm{m}$ (NC)

$<2 \mathrm{~mm}$ to $>63 \mu \mathrm{m}(\mathrm{C})$

$<63 \mu \mathrm{m}(\mathrm{NC})$

$<63 \mu \mathrm{m}(\mathrm{C})$

\section{Bedrock}

Non-carbonate (NC)

Carbonate (C)
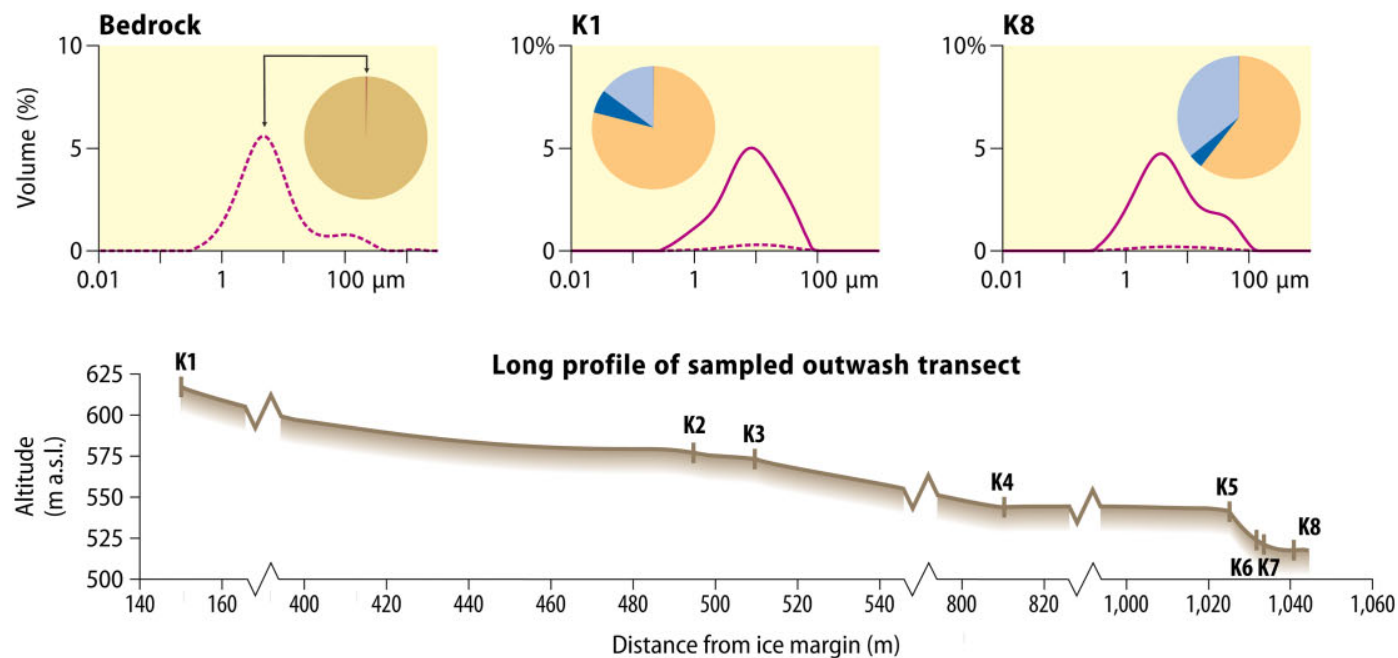

Fig. 5. (a) Key sedimentary logs for Pleistocene fluvial sediments from Kameno alluvial fan. Facies codes follow the legend in Fig. 4.

(b) Pie charts for till and outwash show bulk $(<2 \mathrm{~mm})$ lithology. Particle size curves for till and outwash are for the fraction $<63 \mu \mathrm{m}$. Solid lines $=$ non-acidified samples, dashed lines $=$ insoluble residue component. 
tocene cold stages, meltwater and sediment would have been delivered to the polje via bedrock gorges and across the plateau (type 1 meltwater route). Three lithofacies have been identified in this polje and each is exposed in a stacked sequence at section U3 which is $c .2 .3 \mathrm{~km}$ down valley of the MIS 6 moraines. The basal facies (U3a) comprises well stratified fluvial sands and gravels. The complex PSD of the $<2 \mathrm{~mm}$ fraction reflects the interstratification of fine silts and clays with coarser, granule-rich sediments (Fig. 6a). The $<63 \mu \mathrm{m}$ PSD shows similar particle size characteristics to the ice distal sites at Dvrsno polje and Kameno fan. Insoluble residue accounts for 3.3\% of this fine sediment fraction, and up to $7.0 \%$ of the $<2 \mathrm{~mm}$ matrix (Table 4). These non-limestone lithologies account for up to $20.6 \%$ of the sand fraction, perhaps reflecting the preferential deposition of higher density particles. The overlying till (facies U3b) is also exposed at section U2. The particle size characteristics of the two sites contrast markedly. Facies U3b shows an elevated insoluble residue component $(26.2 \%)$, whilst in the deposits up-valley it is $4.8 \%$ (section U2) (Table 4). The uppermost alluvial facies (U3c) is exposed up-valley at section U1 where the stratified sands and gravels contain a minor $<63 \mu \mathrm{m}$ matrix component $(7.5 \%)$ (Table 4$)$ and an insoluble residue fraction of just $2.2 \%$.

\section{Summary of all outwash sites}

The meltwater routes, grain size distributions, and insoluble residue data for all 12 glacial outwash study sites surrounding Orjen are summarised in Table 5. These are situated downstream of either type 1 or type 2 meltwater routes (Fig. 2). The matrix samples reflect the sedimentary signatures observed within the three sites (Dvrsno, Kameno, and Unijerina) described in detail above. Sites situated downstream of type 1 pathways typically display an increasingly bimodal PSD with distance from the ice margin. Sites situated downstream of type 2 pathways, where meltwater is delivered directly from the ice margin, retain the dominantly unimodal PSD observed within the till matrix samples.

\section{Discussion \\ Controls on particle size distribution}

Two dominant outwash routes have been identified around the Orjen massif. At type 1 meltwater routes, alluvial sediments have been transported via bedrock gorges or across the higher altitude plateau. At the shorter type 2 meltwater routes, sediment was delivered directly from the ice margins. Woodward et al. (2008) have described similar kinds of meltwater routes in the limestone-dominated Voidomatis River basin in northwest Greece. In their study, meltwater route 1 drained the high-altitude plateau directly into the Vikos Gorge through the Megas Laccos Canyon. This system resembles meltwater route type 1 on the Orjen massif. Meltwater route 2 of Woodward et al. (2008) represents the termination of Pleistocene glaciers within the upper Voidomatis Valley, and more closely resembles the type 2 meltwater route in this study. The Pleistocene sedimentary records of Orjen have provided a valuable opportunity to systematically explore the grain size modification of limestone bedrock within such settings.

The fine matrix component of the Orjen glacial deposits displays a broad unimodal PSD $(1-14 \mu \mathrm{m})$. This fraction is dominated by clay and very fine silt $(<8 \mu \mathrm{m})$ and is similar to the PSD of the matrix in the limestone-rich glacial sediments of Mount Tymphi in northwest Greece where $40 \%$ of the bulk matrix sediment is $<63 \mu \mathrm{m}$ (Woodward et al. 1995). As expected, in the case of Orjen, the grain size characteristics of these fine sediments are modified within the proglacial fluvial environment. However, detailed particle size analysis also reveals that the two kinds of meltwater route have produced distinctive sedimentological signatures.

Fine sediments downstream of type 1 routes typically display a bimodal PSD, while those delivered directly from the ice margin (type 2; such as at Vrbanje, Dvrsno transect A, and Sniježnice) more closely resemble the normally distributed PSD of the glacial tills. Importantly, the changes we have observed occur over relatively short distances $(<1.5 \mathrm{~km}$ from the ice margin) within the proglacial zone. This downstream shift towards bimodal PSDs is marked by the selective depletion of the fine silt $(6-20 \mu \mathrm{m})$ carbonate component and the increasing concentration of clay-sized noncarbonate material, as fine glacigenic sediments are modified within the fluvial environment. These particle size signatures have been observed within other studies of meltwater environments and have been attributed to chemical weathering (Reynolds and Johnson 1972; Nesbitt and Young 1996; Tranter 2003) and/or mechanical sorting processes (Garzanti et al. 2009). 


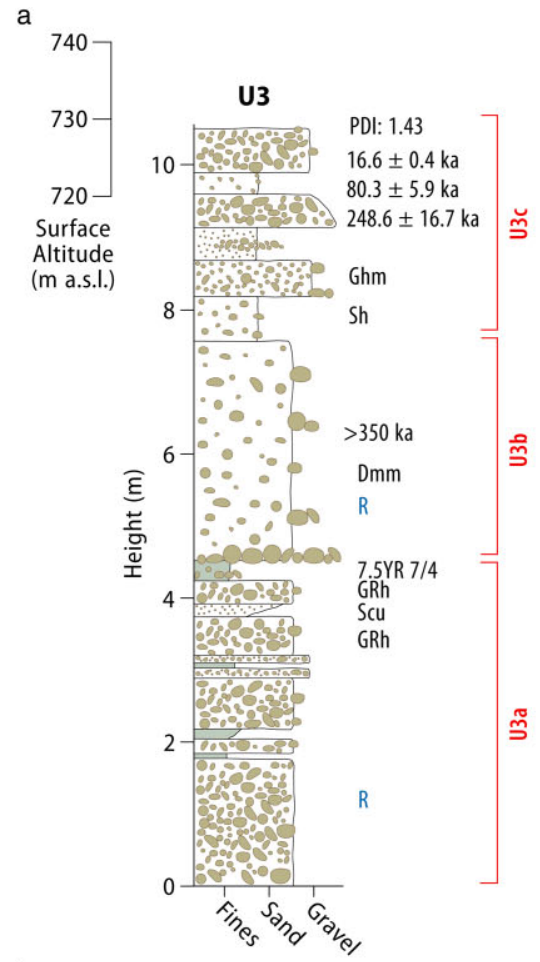

b
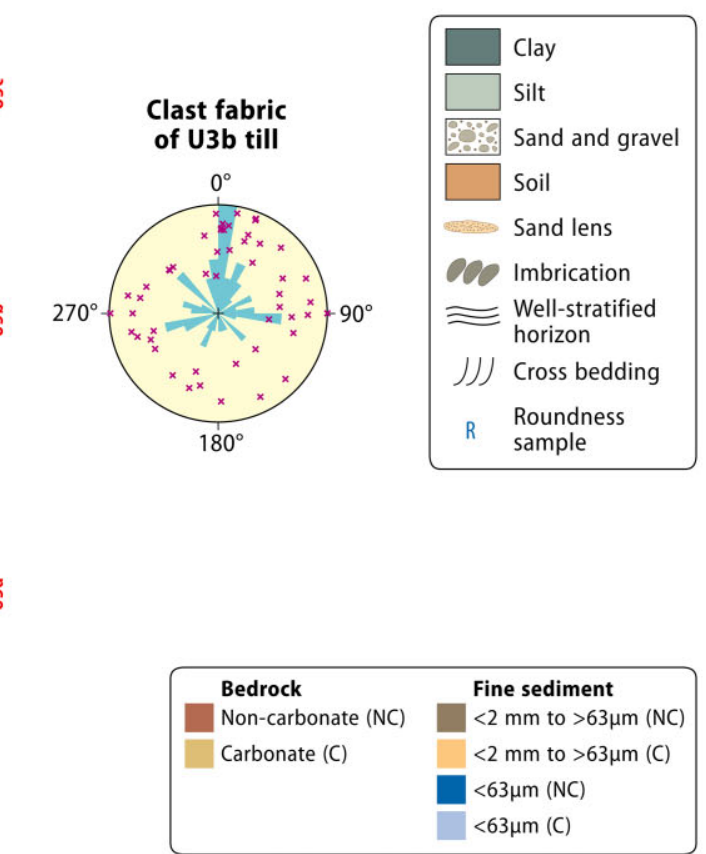

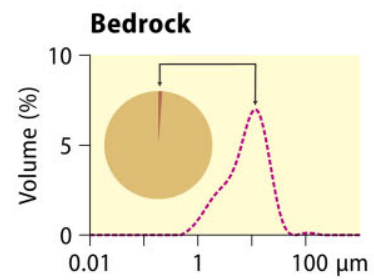

Crkvice till

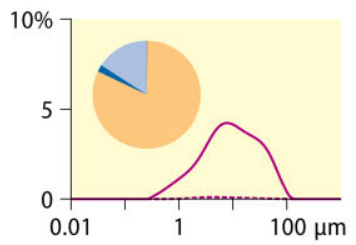

U2
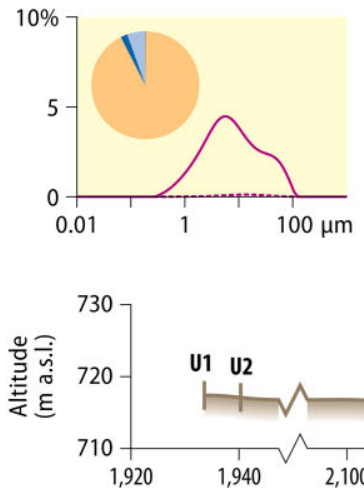

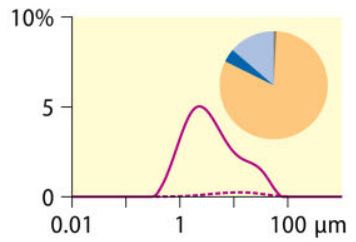

Long profile of sampled outwash transect

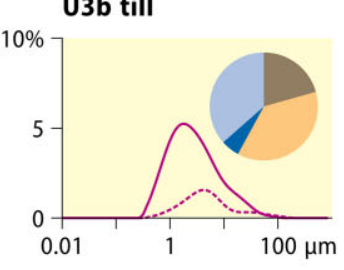

U3a

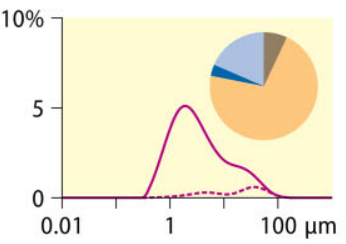

Fig. 6. (a) Key sedimentary logs from Unijerina polje. Facies codes follow the legend in Fig. 4. (b) Pie charts for till and outwash show bulk $(<2 \mathrm{~mm})$ lithology. Particle size curves for till and outwash are for the fraction $<63 \mu \mathrm{m}$. Solid lines = non-acidified samples, dashed lines $=$ insoluble residue component. 
Table 5. MWRs and grain size characteristics of matrix samples from the 12 alluvial sites surrounding Orjen.

\begin{tabular}{|c|c|c|c|}
\hline Site and context & $\begin{array}{l}\text { Distance from ice margin } \\
\qquad(\mathrm{km})\end{array}$ & $\begin{array}{l}\text { MWR } \\
\text { type }\end{array}$ & $\begin{array}{l}\text { Dominant matrix PSD } \\
\qquad(<63 \mu \mathrm{m})\end{array}$ \\
\hline Grahovo polje & 1.40 & 1 & Unimodal \\
\hline Dvrsno polje (transect B) & 2.80 & 1 & Bimodal \\
\hline Crkvice polje & 2.00 & 1 & Bimodal \\
\hline Unijerina polje & $>1.90$ & 1 & Bimodal \\
\hline Kruševice polje & $>1.90$ & 1 & Bimodal \\
\hline Nudo valley & $>0.50$ & 1 & Unimodal \\
\hline Dvrsno polje (transect A) & $>0.90$ & 2 & Unimodal \\
\hline Sniježnice fan & 0.12 & 2 & Unimodal \\
\hline Ubli valley & 1.50 & 2 & Unimodal \\
\hline Kameno fan & $>0.15$ & 2 & Uni/bimodal \\
\hline Vrbanje polje & 1.40 & 2 & Unimodal \\
\hline Pirina Poljana polje & 4.40 & 2 & Unimodal \\
\hline
\end{tabular}

Proglacial environments are conducive to chemical weathering for a number of reasons. The high discharge regime and efficient aeration of meltwater streams replenishes the acidity of the water (Reynolds and Johnson 1972; Tranter 2003). Meltwater would have flowed under highly turbulent conditions in the deeply incised gorges surrounding Orjen (type 1 routes). The abundant supply of freshly comminuted, highly reactive particles from the glacier front provided material that was especially susceptible to dissolution (Reynolds and Johnson 1972). Carbonate-rich lithologies produce distinctive meltwater chemistry and may significantly alter water-rock interactions (Fairchild et al. 1994; Tranter et al. 1993; Anderson et al. 1997; Blum et al. 1998; Skidmore et al. 2004). Furthermore, the low temperature of glacial meltwaters also enhances the dissolution of carbonate particles (Anderson et al. 2000). Evidence from the limestone-rich catchments of Svalbard (Tranter 2003) and metagraywackedominated regions of Alaska (Anderson et al. 2000) suggests that chemical weathering is particularly prevalent in the proglacial zone due to the abundance of carbonate lithologies, soil development and colonisation of floodplains by tundra vegetation. In the carbonate-rich catchment of Glacier de Tsanfleuron, Switzerland, for example, Fairchild et al. (1994) found that the trace element concentration $(\mathrm{Mg} / \mathrm{Ca}$ and $\mathrm{Sr} / \mathrm{Ca})$ of glacial meltwater was considerably higher than the parent bedrock, indicating its progressive concentration downstream. Even within carbonate-poor basins, such as the Haut Glacier D'Arolla (carbonate content of sediments $c$. 1\%), solute fluxes were found to be elevated in carbonate trace elements, such as $\mathrm{Ca}^{2+}$ and $\mathrm{Mg}^{2+}$ (Brown et al. 1996; Fairchild et al. 1999). This process may be due to the preferential or incongruent dissolution of calcite, but may also reflect the presence of freshly exposed mineral surfaces due to glacial crushing, which enhances the release of trace cations (see discussion in McGillen and Fairchild 2005). Within active, carbonate-rich, glacial environments, crushing and various dissolution processes are all likely to play an important role in both sediment particle size characteristics and meltwater chemistry (McGillen and Fairchild 2005).

Large quantities of silt are produced by crushing and abrasion in the sub-glacial traction zone (Smalley 1990; Assallay et al. 1998). If exported to the proglacial fluvial environment, this material can form an important source of wind-blown dust (Smalley 1995). The large depocentres surrounding the Orjen massif were filled with limestonerich outwash sediments during the major glacial phase of MIS 12 (Hughes et al. 2010; Adamson et al. 2014). Our data show that the $10-60 \mu \mathrm{m}$ component is strongly depleted or absent in the bimodal fine-grained matrix samples, especially in those collected from poljes downstream of type 1 pathways. The 10-60 $\mu \mathrm{m}$ component matches the particle size characteristics of typical loess (Pye 1987). The wide braidplains of the largest poljes would have been especially favourable settings for the deflation of fine-grained carbonaterich silt.

\section{Lithological variations}

Since the properties of the parent bedrock exert an important control on the nature of fine glacial 
sediments (see Jørgensen 1977; Haldorsen 1981), the broadly uniform composition of the limestones of Mount Orjen provides an ideal field setting for this study. Our data show that some of the limestone silts and clays soon become depleted in the proglacial fluvial environment and can be replaced by non-carbonate lithologies. Evidence from the PSD of the glacial till suggests that this process is already underway within the glacial environment. Limestone bedrock samples typically contain $<3.6 \%$ insoluble residue. This insoluble residue is concentrated in the $2-11 \mu \mathrm{m}$ size fraction and displays a normally distributed PSD. As the bedrock is comminuted within the glacial environment, till is produced with insoluble residues ranging from $2.1 \%$ to $15.8 \%$ (Table 3). Within the proglacial environment, the proportion of insoluble residue increases markedly - it is as high as $20.5 \%$ in the fine fraction at Nudo and Dvrsno. Significantly, in the alluvial environment, the $<63 \mu \mathrm{m}$ insoluble residue becomes concentrated at the minimum point of the bulk sample bimodal curve $(2-11 \mu \mathrm{m})$ and reflects the concentration of non-limestone lithologies into specific size fractions. This may be due to glacial erosion and chemical weathering as well as the mechanical sorting of higher density non-carbonate clays derived from the more impure carbonate rocks within the catchment. Denser grains become concentrated into the finer fractions of sorted sediments as they preferentially settle from suspension when meltwater streams lose competence (Nesbitt and Young 1996; Garzanti et al. 2008, 2009, 2010), while carbonate grains are winnowed during transport downstream (Woodward et al. 1995; Garzanti et al. 2009). It is also likely that a proportion of the suspended load becomes aggregated into larger composite particles. These processes have been observed within Pleistocene and contemporary meltwater systems in the Mediterranean and elsewhere (Reynolds and Johnson 1972; Nesbitt and Young 1996; Woodward et al. 2002; Tranter 2003; Garzanti et al. 2008, 2009, 2010; von Eynatten et al. 2012).

In the case of our outwash matrix samples, the observed PSDs and lithological characteristics are a combination of both the chemical preparation of non-carbonate lithologies, and their mechanical concentration within the fluvial environment

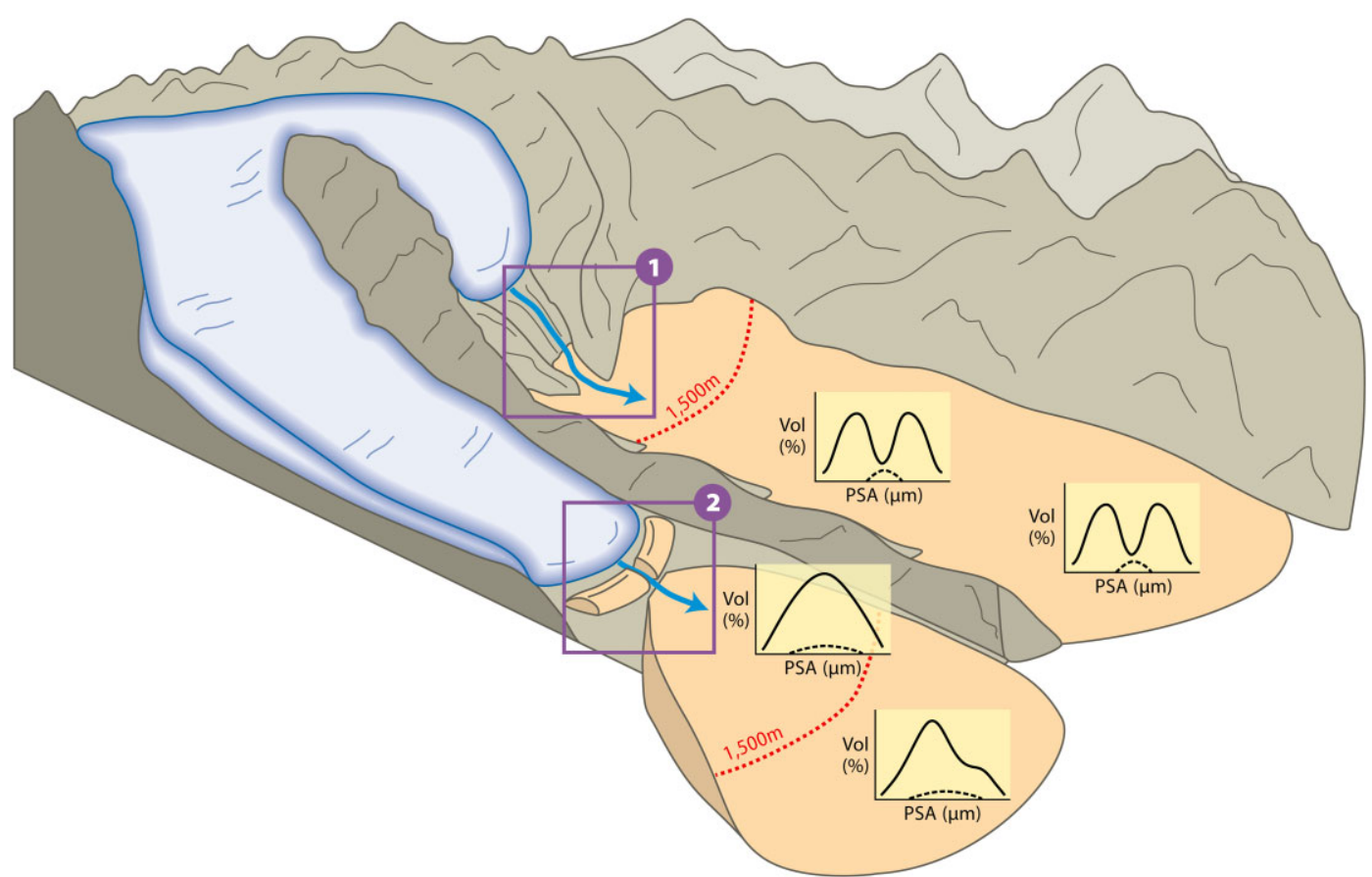

Fig. 7. Schematic representation of the meltwater routes and particle size distributions of carbonate (solid line) and non-carbonate (dashed line) sediments within the outwash deposits. 


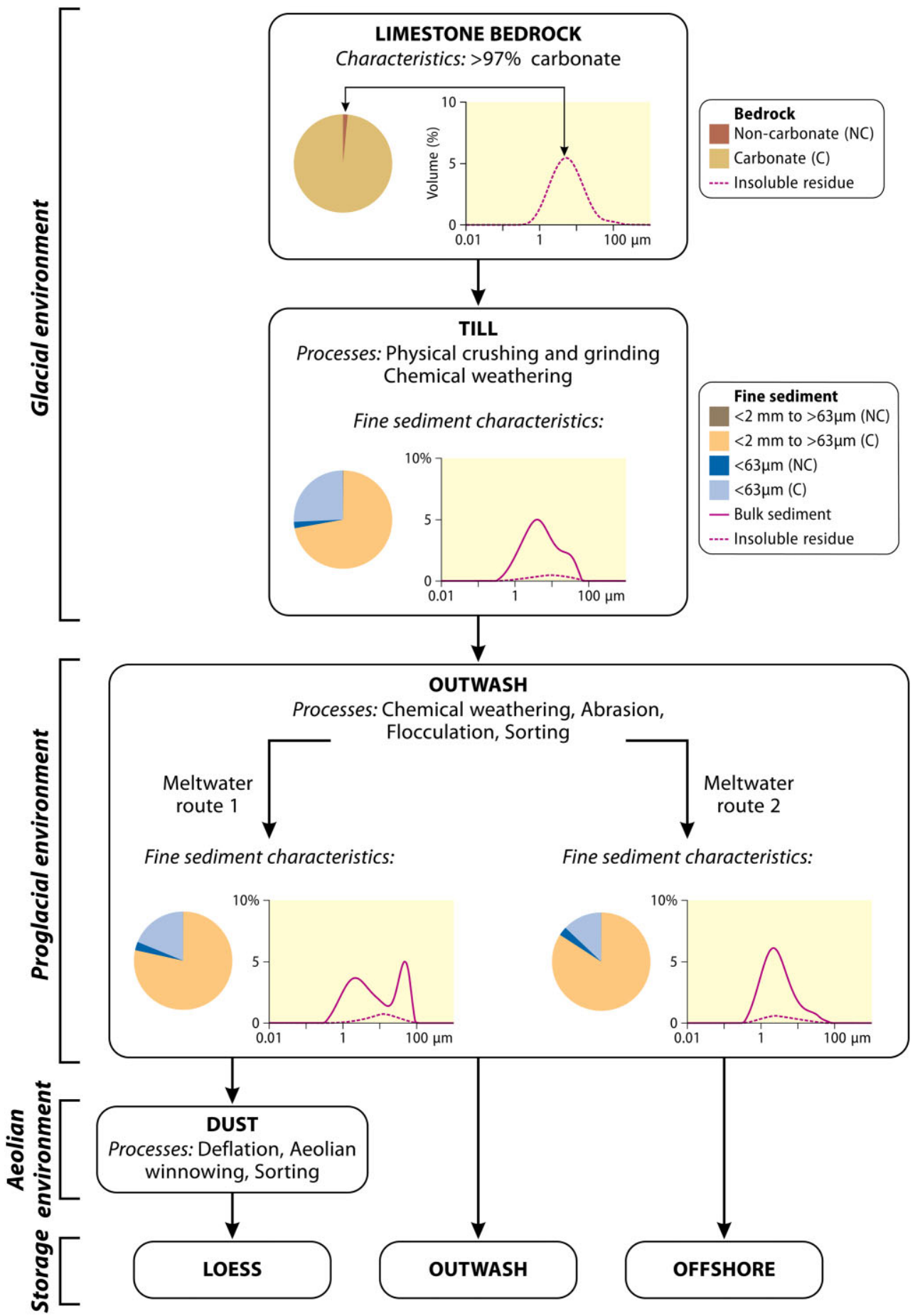

Fig. 8. Schematic model of the grain size modifications within the glacial and proglacial fluvial environments around Mount Orjen showing the dominant processes and the resulting particle size distributions. 
through size-density sorting. Limestone particles have a specific gravity of 2.20-2.60 compared with 2.65 for quartz. Some of this lower density carbonate silt may have been transported farther downstream and offshore into the Bay of Kotor, but this component has not yet been explored.

\section{Ice marginal controls on sediment transformation}

The position of the Pleistocene ice margin appears to have exerted an important influence on the PSD and lithological composition of alluvial sediments in the proglacial zones around the Orjen massif. Particle size data for the fine sediment matrix $(<63 \mu \mathrm{m})$ have been used to characterise the contrasting ice marginal positions, meltwater pathways, and depositional settings surrounding the massif (Fig. 7). In general, sites situated $<1.5 \mathrm{~km}$ from the MIS 12 ice moraines typically contain massive, crudely to well stratified gravels. The fine matrix fraction $(<63 \mu \mathrm{m})$ of these deposits typically displays a unimodal PSD. Sediments deposited $>1.5 \mathrm{~km}$ from the ice front comprise interstratified gravels, sands and fines. The fine matrix $(<63 \mu \mathrm{m})$ here is typically dominated by a bimodal PSD (Table 4). The particle size evidence indicates that even over relatively short transport distances (c. $1.5 \mathrm{~km}$ ), fine-grained glacigenic sediments undergo considerable modification within the proglacial fluvial environment.

These findings can be used to propose a model of the dominant erosion and weathering processes acting upon limestone bedrock, and the resulting fine sediment matrix signatures, within glacial and fluvial environments (Fig. 8). The model shows that downstream of type 1 meltwater routes (bedrock gorges), the fine sediment matrix becomes increasingly bimodally distributed. This progressive weathering and sorting of the limestone-derived fines leads to the downstream concentration of non-carbonate grains. The PSD of outwash matrix samples downstream of type 2 meltwater routes show evidence of medium and coarse silt depletion relative to the till source. During Pleistocene cold stages, glacially comminuted, fine matrix material $(<63 \mu \mathrm{m})$ was readily available for aeolian entrainment within the proglacial fluvial environment and may have contributed significant volumes of limestone silt to the loess deposits of Eastern Europe (Marković et al. 2009, 2011). It is also likely that this suspended sediment was delivered in considerable quantities to marine environments during Pleistocene cold stages
(Fig. 8). Understanding the transport history of these sediments, from the bedrock source area to the glacial and fluvial environments, is therefore important for their identification within other terrestrial and marine settings.

\section{Conclusions}

This is the first systematic study of the modification of limestone bedrock and fine-grained sediment in a Pleistocene glaciofluvial environment. Understanding the modification of this material, as it is transported downstream, is important for its identification within a range of depositional sinks. Two kinds of Pleistocene surface meltwater route have been documented on Mount Orjen (Fig. 2). At type 1 routes, ice was constrained to the high altitude plateau so that outwash was transferred downstream via bedrock gorges. At type 2 routes, ice extended beyond the plateau and into the surrounding depocentres where outwash was delivered directly from the ice margin. Fine-grained fluvial sediments downstream of the type 1 routes typically display a bimodal grain size distribution, where the fine silt fraction is much reduced. This depleted carbonate-rich silt fraction matches the particle size characteristics of typical loess. We also see evidence of coarser silt depletion in the outwash deposits associated with type 2 meltwater routes. It is likely that the fine-grained sediment exported from the glaciated limestone uplands of the Mediterranean formed an important source of carbonate-rich dust that contributed to the loess deposits of the region.

Kathryn R. Adamson, Geography, School of Science and the Environment, Manchester Metropolitan University, Manchester M1 5GD, UK

Email: k.adamson@mmu.ac.uk

Jamie C. Woodward and Philip D. Hughes, Geography, School of Environment, Education, and Development, The University of Manchester, Manchester M13 9PL, UK

Email: jamie.woodward@manchester.ac.uk; philip.hughes @ manchester.ac.uk

\section{Acknowledgements}

The authors would like to thank the Guest Editors and reviewers for their very helpful comments on the manuscript. Thanks also to Tim Lane for assistance with sample collection in the field and to the laboratory staff at The University of Manchester for technical support during sample analysis. This work was supported by a $\mathrm{PhD}$ Studentship from the 
School of Environment, Education and Development (Geography) at The University of Manchester in the Quaternary Environments and Geoarchaeology Research Group. Fieldwork was funded through the kind support of postgraduate research grants from: the Quaternary Research Association; The Geological Association; the British Society for Geomorphology; and the Manchester Geographical Society. We thank Nick Scarle for drawing the figures.

\section{References}

Adamson, K.R., Woodward, J.C. and Hughes, P.D., 2014. Glaciers and rivers: Pleistocene uncoupling in a Mediterranean mountain karst. Quaternary Science Reviews, 94, 28-43.

Anderson, S.P., Drever, J.I. and Humphrey, N.F., 1997. Chemical weathering in glacial environments. Geology, 25 (5), 399-402.

Anderson, S.P., Drever, J.I., Frost, C.D. and Holden, P., 2000. Chemical weathering in the foreland of a retreating glacier. Geochimica et Cosmochimica Acta, 64 (7), 1173-1189.

Assallay, A.M., Rogers, C.D.F., Smalley, I.J. and Jefferson, I.F., 1998. Silt: 2-62 $\mu \mathrm{m}, 9-4 \varphi$. Earth-Science Reviews, 45 (1), 61-88.

Blum, J.D., Gazis, C.A., Jacobson, A.D. and Chamberlain, C.P., 1998. Carbonate versus silicate weathering in the Raikhot watershed within the High Himalayan Crystalline Series. Geology, 26 (5), 411-414.

Brown, G.H., Sharp, M. and Tranter, M., 1996. Subglacial chemical erosion: seasonal variations in solute provenance, Haut Glacier d'Arolla, Valais, Switzerland. Annals of Glaciology, 22, 25-31.

Fairchild, I.J., Bradby, L. and Spiro, B., 1994. Reactive carbonate in glacial systems: a preliminary synthesis of its creation, dissolution and reincarnation. In: Deynoux, M., Miller, J.M.G., Domack, E.W., Eyles, N., Fairchild, I.J. and Young, G.M. (eds.) Earth's glacial record IGCP Project 260. Cambridge University Press, Cambridge. 176-192.

Fairchild, I.J., Killawee, J.A., Hubbard, B. and Dreybrodt, W., 1999. Interactions of calcareous suspended sediment with glacial meltwater: a field test of dissolution behaviour. Chemical Geology, 155 (3-4), 243-263.

Garzanti, E., Andò, S. and Vezzoli, G., 2008. Settling equivalence of detrital minerals and grain-size dependence of sediment composition. Earth and Planetary Science Letters, 273, 138-151.

Garzanti, E., Andò, S., France-Lanord, C., Vezzoli, G., Censi, P., Galy, V., and Najman, Y, 2010. Mineralogical and chemical variability of fluvial sediments 1 . Bedload sand (Ganga-Brahmaputra, Bangladesh). Earth and Planetary Science Letters, 299, 368-381.

Garzanti, E., Andò, S. and Vezzoli, G., 2009. Grain-size dependence of sediment composition and environmental bias in provenance studies. Earth and Planetary Science Letters, 277, 422-432.

Giraudi, C., Bodrato, G., Ricci Lucchi, M., Cipriani, N., Villa, I.M., Giaccio, B. and Zuppi, G. M., 2011. Middle and Late Pleistocene glaciations in the Campo Felice basin (Central Apennines-Italy). Quaternary Research, 75, 219-230.

Goossens, D., 2008. Techniques to measure grain-size distributions of loamy sediments: a comparative study of ten instruments for wet analysis. Sedimentology, 55, 6596.

Haldorsen, S., 1981. Grain-size distribution of subglacial till and its relation to glacial crushing and abrasion. Boreas, 10, 91-105.

Hughes, P.D. and Woodward, J.C., 2009. Glacial and Periglacial Environments. In: Woodward, J.C. (ed.) The Physical Geography of the Mediterranean. Oxford University Press, Oxford. 357-383.

Hughes, P.D., Woodward, J.C., van Calsteren, P.C., Thomas, L.E. and Adamson, K.R., 2010. Pleistocene ice caps on the coastal mountains of the Adriatic Sea. Quaternary Science Reviews 29 (27-28), 3690-3708.

Jørgensen, P., 1977. Some properties of Norwegian tills. Boreas, 6, 149-157.

Konert, M. and Vandenberghe, J. 1997. Comparison of laser grain size analysis with pipette and sieve analysis: a solution for the underestimation of the clay fraction. Sedimentology, 44, 523-535.

Lewin, J., Macklin, M.G. and Woodward, J.C., 1991. Late Quaternary fluvial sedimentation in the Voidomatis Basin, Epirus, northwest Greece. Quaternary Research, 35, 103-115.

Lewin, J. and Woodward, J.C., 2009. Karst geomorphology and environmental change. In: Woodward, J.C. (ed.), The Physical Geography of the Mediterranean. Oxford University Press, Oxford. 287-317.

Magaš, D., 2002. Natural geographic characteristics of the Boka Kotorska area as the basis of development. Geoadria, 7 (1), 51-81.

Marković, S.B., Hambach, U., Catto, N., Jovanović, M., Buggle, B., Machlett, B., Zöller, L., Glaser, B. and Frechen, M., 2009. Middle and late Pleistocene loess sequences at Batajnica, Vojvodina, Serbia. Quaternary International, 198, 255-266.

Marković, S.B., Hambach, U., Stevens, T., Kukla, G.J., Heller, F., McCoy, W.D., Oches, E.A., Buggle, B. and Zöller, L., 2011. The last million years recorded at the Stari Slankamen (Northern Serbia) loess-palaeosol sequence: revised chronostratigraphy and long-term environmental trends. Quaternary Science Reviews, 30 (9), 1142-1154.

McCave, I.N., Hall, I.R. and Bianchi, G.G. 2006. Laser vs. settling velocity differences in silt grain size measurements: estimation of palaeocurrent vigour. Sedimentology, 53, 919-928.

McGillen, M.R. and Fairchild, I.J. 2005. An experimental study of incongruent dissolution of $\mathrm{CaCO}_{3}$ under analogue glacial conditions. Journal of Glaciology, 51, 383390.

Nesbitt, H.W. and Young, G.M., 1996. Petrogenesis of sediments in the absence of chemical weathering: effects of abrasion and sorting on bulk composition and mineralogy. Sedimentology, 43, 341-358.

Pye, K., 1987. Aeolian Dust and Dust Deposits. London: Academic Press. 334 p.

Reynolds Jr, R.C. and Johnson, N.M., 1972. Chemical weathering in the temperate glacial environments of the 
Northern Cascade Mountains. Geochimica et Cosmochimica Acta, 36, 537-554.

Skidmore, M., Sharp, M. and Tranter, M., 2004. Kinetic isotopic fractionation during carbonate dissolution in laboratory experiments: implications for detection of microbial $\mathrm{CO}_{2}$ signatures using $\mathrm{d}^{13} \mathrm{C}$-DIC. Geochimica et Cosmochimica Acta, 68 (21), 4309-4317.

Smalley, I., 1990. Possible formation mechanisms for the modal coarse-silt quartz particles in loess deposits. Quaternary International, 7, 23-27.

Smalley, I., 1995. Making the material: the formation of silt sized primary mineral particles for loess deposits. Quaternary Science Reviews, 14 (7), 645-651.

Sperazza, M., Moore, J. N. and Hendrix, M. S., 2004. High resolution particle size analysis of naturally occurring very fine grained sediment through laser diffractometry. Journal of Sedimentary Research, 747 (5), 36-743.

Syvitski, J.P.M., Leblanc, K.W.G. and Asprey, K.W., 1991. Interlaboratory instrument calibration experiment. In: Syvitski, J.P.M. (ed.), Principles, Methods and Application of Particle Size Analysis. Cambridge University Press: Cambridge. 174-193.

Tranter, M., 2003. Geochemical weathering in glacial and proglacial environments. In: Drever, J.I. (ed.), Treatise on Geochemistry 5. Elsevier. 189-205.

Tranter, M., Brown, G., Raiswell, R., Sharp, M. and Gurnell, A., 1993. A conceptual model of solute acquisition by Alpine glacial meltwaters. Journal of Glaciology, 39 (133), 573-581.

von Eynatten, H., Tolosana-Delgado, R. and Karius, V., 2012. Sediment generation in modern glacial settings:
Grain-size and source-rock control on sediment composition. Sedimentary Geology, 280, 80-92.

Woodward, J.C. and Bailey, G.N., 2000. Sediment sources and terminal Pleistocene geomorphological processes recorded in rockshelter sequences in Northwest Greece. In: Foster, I.D.L. (ed.), Tracers in Geomorphology, Wiley: Chichester. 521-551.

Woodward, J.C., Hamlin, R.H.B., Macklin, M.G., Hughes, P.D. and Lewin, J., 2008. Glacial activity and catchment dynamics in northwest Greece: Long-term river behaviour and the slackwater sediment record for the last glacial to interglacial transition. Geomorphology, 101, 44 67.

Woodward, J.C., Lewin, J. and Macklin, M.G., 1992. Alluvial sediment sources in a glaciated catchment: the Voidomatis basin, northwest Greece. Earth Surface Processes and Landforms, 17, 205-216.

Woodward, J.C., Lewin, J. and Macklin, M.G., 1995. Glaciation, river behaviour and the Palaeolithic settlement of upland northwest Greece. In: Lewin, J., Macklin, M.G. and Woodward, J.C. (eds), Mediterranean Quaternary River Environments. Balkema, Rotterdam. 115129.

Woodward, J.C., Porter, P.R., Lowe, A.T., Walling, D.E. and Evans, A.J., 2002. Composite suspended sediment particles and flocculation in glacial meltwaters: preliminary evidence from Alpine and Himalayan basins. Hydrological Processes, 16, 1735-1744.

Manuscript received 25 Jan., 2014, revised and accepted date 9 Jun., 2014 